\title{
Evidence-based publications on upper secondary education in Iceland, 2003-2012
}

\author{
Guðrún Ragnarsdóttir, Assistant Professor, School of Education, Univer- \\ sity of Iceland \\ Ingólfur Ásgeir Jóhannesson, Professor, School of Education, University \\ of Iceland
}

Jón Torfi Jónasson, Professor Emeritus, School of Education, University of Iceland
Brynja E. Halldórsdóttir, Assistant Professor, School of Education, Univer- sity of Iceland

\begin{abstract}
Globally, there is a demand for basing education policy decisions and practice on solid evidence. While the same applies in Iceland, some have claimed that there is a dearth of evidence-based publications targeted at education. This article considers this claim by examining the availability and nature of evidencebased publications with a focus on upper secondary education in Iceland. In total, the main characteristics of 316 publications were studied over the period 2003-2012. These publications included peer-reviewed articles, non-reviewed scholarly work (articles and reports), master's and doctoral theses, external evaluation reports, and innovation reports. The findings reveal a hidden treasure of a number of publications targeted at upper secondary education in Iceland. Some educational fields are still weakly represented in the evidence spectrum, such as vocational studies, and the data collection methods are relatively few. Furthermore, the main stakeholders are isolated from one another to a degree. Such isolation is problematic, as evidence-based publications are intended to inform both policy and practice. Thus, the study suggests an increased need for cooperation among the main stakeholders in upper secondary education.
\end{abstract}

Keywords: Upper secondary education; evidence-based publications; university-based publications; evaluation reports; innovation reports. 


\section{Introduction}

The emphasis of the 21 st century academic world in the field of education is on publishing research articles in peer-reviewed journals (Bornmann \& Mutz 2014; Larsen \& von Ins 2010). The global growth of such publications has been considerable. The same applies to the growth of a variety of other data-driven publications. Associated materials are now available at the international level, for instance, PISA data, in various domestic external evaluation reports (Ministry of Education, Science and Culture 2010), and in innovation reports from the Innovation Fund (Sprotasjóður n.d.). We will refer to this kind of material as evidence-based publications. The demand to inform both education policy and practice through available data and solid evidence has increased; this is particularly relevant concerning decisions related to educational change and general school improvement (Cooper, Levin, \& Campbell 2009; Hammersley 2005; Lingard \& Gale 2010; Morrison 2007; Sleeter 2014; Yates 2004).

Earlier studies in Iceland indicate that a limited number of research publications focused on upper secondary education (Guðmundsson 2009; Jóhannesson 2007; Jóhannsdóttir \& Jónasson 2014; Thorarensen, Vilmundarson, \& Hilmarsson 2008) and that little is known about other kinds of evidence-based publications and their implications for the country. This article investigates the availability and nature of evidence-based publications related to Icelandic upper secondary education during 2003-2012. The study relies on data from a wide range of publications, including peer-reviewed publications, non-reviewed scholarly work (articles and reports), theses (PhD and master's), external evaluation reports, and innovation reports. We documented and categorised 316 publications based on their types, data collection methods, content, target audience, and the mode of publication. This study builds on the work of Kaldalóns and Macdonald (2005), who mapped publications about the educational system in Iceland, from preschool to universities, as well as the non-formal educational system. The previous study from 1998-2002 indicated that there were limited evidence-based publications related to upper secondary education in Iceland.

\section{Conceptual background}

Mortimore (2000) argues that scientific research publications in education confront and explore complex and diverse aspects of education for many different purposes. Scientific research is described as a critical systematic enquiry for gathering information and analysing it in order to improve knowledge in society. Data collected systematically and analysed with attention to transparency, validity, and reliability characterise scientific educational research. The data collected takes many forms, often numerical but also visual or verbal (McMillan 2012; Mortimore 2000).

The vast majority of the publications is produced within universities. Most importantly, university-based researchers primarily aim at publishing peer-reviewed articles and books. Lingard and Gale (2010) suggest that we look at scientific research in education from a broader perspective rather than only from the perspective of peer-reviewed journals. They advocate for diverse and multidimensional perspectives and approaches. 
Guđrún Ragnarsdóttir

Ingólfur Ásgeir Jóhannesson

Jón Torfi Jónasson

Brynja E. Halldórsdóttir
STJÓRNMÁL

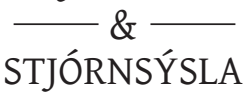

This broadens the research spectrum to include non-reviewed scholarly work, for instance, articles in professional journals and various kinds of reports. There is also a good number of theses falling under this category, such as $\mathrm{PhD}$ and master's theses, written by university students in cooperation with university-based researchers. Lingard and Gale (2010) also note that, within education, data is collected on the operation of schools. This can be through internal evaluation, where data are collected within the organisation, or external evaluation, where an independent agent writes a report on individual schools. These can sometimes be based in part on the internal evaluation, such as in Iceland (Ministry of Education, Science and Culture 2010).

According to Puddy and Wilkins (2011), the meaning of the term evidence is vague. Commonly, in order to be considered evidence, the data collection must follow certain standards, often through rigid procedures. Evidence gathered in university-based research is normally theoretically-oriented, sometimes with a rather narrow focus meant to support a certain hypothesis or to clarify a theoretical stance. Systematic evidence may be collected in order to explain a situation, such as the value of certain teaching practices, attitudes towards inclusion, the extent and nature of dropout from school, or national standing vis-a-vis certain norms or competencies as is done in the PISA tests. Similarly, external evaluation reports are carried out according to predetermined criteria, as are reports on innovation activities. They are systematic work, but perhaps less rigorous than in the other cases mentioned above.

Nutley, Powell, and Davies (2013) note that there is a hierarchy of different forms of evidence, where publications are ranked based on their structure and presumed impact. Further, they discuss several challenges entailed with the hierarchy. They note that such a hierarchy neglects other useful forms of evidence than scientific research, fails to understand what works, and gives inadequate recommendations about the efficiency of interventions and whether they should or should not be adopted for implementation. This idea of hierarchy of evidence is helpful in understanding what kinds of evidence are used and considered important or not and by whom.

The authors whose work is discussed above often assume that they are writing for a diverse audience, sometimes more than one group simultaneously, including practitioners in the field, policy makers, university-based researchers, and civil society (Hammersley 2002; Mortimore 2000; Yates 2004). In education, as in other fields, some universitybased researchers are interested mainly in developing theoretical knowledge (Morrison 2007) while others are more interested in educational change (Levin 2004; Morrison 2007; Sleeter 2014; van den Akker et al. 2006; Yates 2004). Yates (2004), however, argues that good education research is preferably carried out in close cooperation with actors in the given field and ought to guide both policy and practice. Evans (2008) brings the argument even closer to the field of practitioners by framing research competences as an important aspect of professionalism and argues that practitioners need to earn their place in society with proficient and disciplined working methods in the arena of evidence. This view supports the current discourse regarding the importance of evidence and the potential to harness these in educational practice and policy. 
Several challenges arise when studying evidence-based publications on education. Hemsley-Brown and Sharp (2003) and Nelson, Leffler, and Hansen (2009) highlight the gap between the available knowledge and the applicability of university-based publications to improve practice. They note that university-based researchers tend to seek out knowledge, while practitioners are looking for new solutions to improve their practices. Similarly, Levin (2004) emphasises the weak link between the universities and practitioners' needs, adding that peer-reviewed publications are written mainly for university audiences instead of adapting the writing to schools, policy makers, or other interest groups.

Sleeter (2014) found that the focus of scientific articles that she evaluated was often somewhat narrow and isolated, rather than holistic, large-scale, and directed towards collaboration. She notes a weak link between the universities and educational practice and found that relatively few of the studies were useful for policy makers. She observes that there is a lack of emerging, shared research designed to inform policy. Thus, she calls for diverse research design, large-scale mixed methods research design, comprehensive knowledge, and more sharing of research agendas through teamwork. Nelson et al. (2009) add that users' time constraints, information overload, and the format of the publications are notable obstacles. In addition, they note that school heads and policy makers consider university-based articles valuable but using them occupied a secondary role in decision-making.

\subsection{Research questions and publications categories}

In light of the discussion about the nature of evidence-based publications, as well as the complaints about the paucity of such material related to Icelandic upper secondary education (Guðmundsson 2009; Jóhannesson 2007; Jóhannsdóttir \& Jónasson 2014; Thorarensen, Vilmundarson, \& Hilmarsson 2008), we pose the following research questions: What is the availability of research and evidence on upper secondary education, and what characterises publications targeting upper secondary education in the beginning of the $21^{\text {st }}$ century? In order to gauge both the type of material, its content and developments over time, the secondary question is: How are the publications distributed among the different research methods, content categories, and target audiences? The latter question is then subdivided into the following questions: In what way has the rate of publication changed over the period of study? Are there trends in the content of the publications?

Based on the conceptual background in the first section, three categories have been defined. The synonym for all publications is evidence-based publications. They fall into three main categories. The first category is university-based publications where we draw on ideas from MacMillan (2012), Mortimore (2000), and Lingard and Gale (2010). The second category is evaluation reports in line with Lingard and Gale (2010) suggestion to consider different kinds of publications rather than only university-based publications. The same applies to the final category, innovation reports (Figure 1). 


\section{STJÓRNMÁL \\ \& \\ STJÓRNSÝSLA}

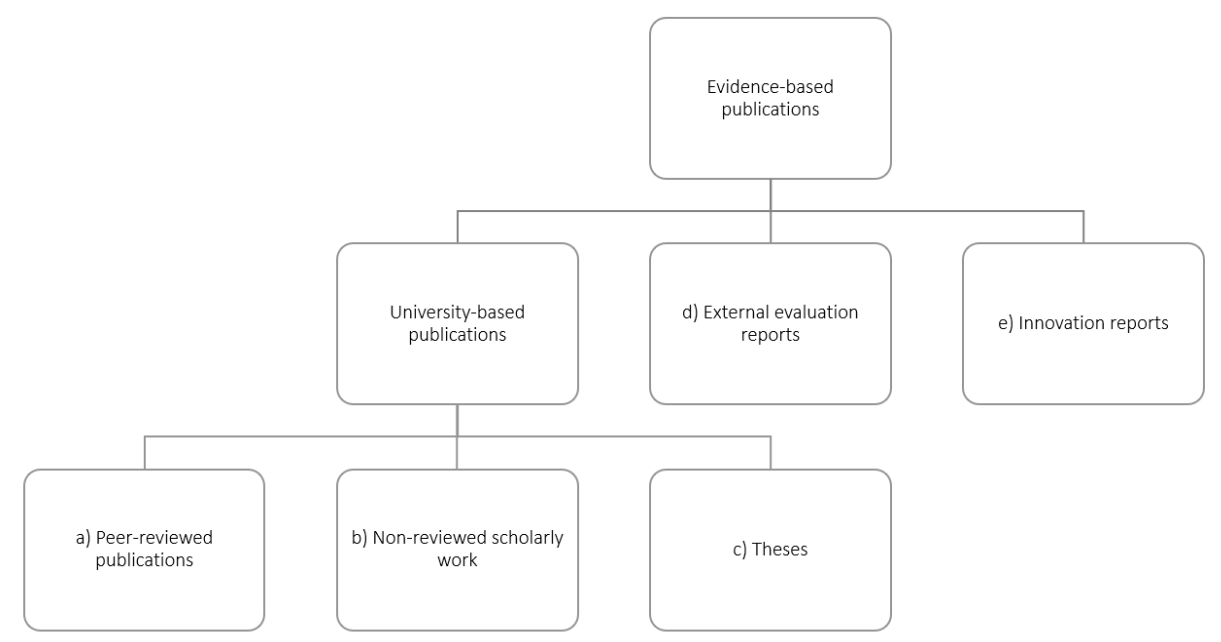

Figure 1. Categories of evidence-based publications

The university-based publications are so named because most of them are written by university-based researchers, including graduate students and recent graduates. They are divided here into three categories: peer-reviewed publications, such as journal articles, books, and book chapters; non-reviewed scholarly work which includes articles in professional journals and reports produced within the universities or in other research institutions; and finally $\mathrm{PhD}$ and master's theses.

In contrast, the work in the two last categories is most often produced outside of universities. External evaluation reports make less use of theories, hypotheses, or other existing academic knowledge. Therefore, they do not fit the category of university-based publications despite the fact that evaluation reports are usually based on data that is systematically collected in a similar way as most university-based publications or even written by university-based researchers. These reports are usually written for policy makers and schools. The fifth category, innovation reports, is the product of governmentally funded innovation activities (Sprotasjóður n.d.), produced in the schools as an outcome report of the innovation activities.

\section{Method}

The study is based on a review of evidence-based publications looking at upper secondary education in Iceland over a ten-year period, including 2003 and 2012, and is an independent continuation of a study that covered the period from 1998-2002 (Kaldalóns \& Macdonald 2005). It was decided that the present study would cover a ten years period, ${ }^{1}$ beginning in 2003 . 


\subsection{Data collection}

Two Icelandic library search engines were used, Gegnir/Leitir, a search engine that covers most Icelandic publications, and Skemman, a repository that houses theses, articles, and various other publications. We also used international search engines for known keywords and Icelandic authors. Moreover, we looked at the most important journals in the field of education in Iceland at the time: Icelandic Journal of Education (Uppeldi og menntun), Journal of Educational Research Iceland (Timarit um menntarannsóknir), Netla-Online Journal on Pedagogy and Education, and Icelandic Review of Politics \& Administration. Finally, we systematically searched several known official web sites for educational organisations, i.e., those of the Ministry of Education, Science, and Culture; the Icelandic Teacher Union; the Sprotasjóður Innovation Fund; and the universities' webpages.

We used the following criteria as tools in the search: names of known universitybased researchers, names of $\mathrm{PhD}$ candidates focusing on upper secondary education, ${ }^{2}$ university webpages, keywords linked to the upper secondary school level (i.e. upper secondary schools/education, students, teachers, comprehensive schools, vocational schools, grammar schools), and publications on websites known to focus on this school level.

In most cases, it was relatively straightforward to determine if the material was aimed at upper secondary education, as this was often explicitly mentioned in the title or among the keywords. But, if it was thought that a publication might refer to this school level, even if it was not explicit, it was scanned for relevant content, and, in some cases, if a publication was judged to be relevant to upper secondary schools even though it had a broader audience.

\subsection{Data analysis}

We found 316 publications that were directly or indirectly aimed at upper secondary education. The publications were read by the first author and sorted along five dimensions of classification (DofC) in consultation with the other authors. These DofCs are as follows: nature of the publications, method, content by using Holbrook et al. (2000), target audience inspired by the quadruple helix model (Park 2014), and formal structure of the publication. Some of these five categories could not be identified for every publication, particularly in the thesis category, as only the abstract was available. Some of the theses were also stored abroad or closed to the wider public and therefore difficult to reach. Thus, we were unable to fill in all parts of the evaluation framework and identified those parts as missing. This explains why some of the tables do not have all the 316 publications assessed.

Starting with DofC 1 (representing the rows in Table 1 and Table 2 in Findings), the classification was carried out to determine the nature of the publications. The 316 publications were grouped as follows within DofC 1: 26 peer-reviewed publications, 97 non-reviewed scholarly works, 116 completed master's and doctoral theses, 41 external evaluation reports, and 36 innovation reports.

DofC 2 (representing the columns in Table 1) was used to identify the data collec- 
Guđrún Ragnarsdóttir

Ingólfur Ásgeir Jóhannesson

Jón Torfi Jónasson

Brynja E. Halldórsdóttir
STJÓRNMÁL

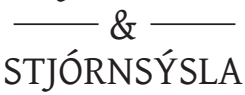

tion methods of the respective publication. Eight different categories were used based on how the authors defined the method used. Each method was placed in one of the following categories: mixed method, mainly qualitative and quantitative; only qualitative; only quantitative; action research; theoretical overview; historical overview; innovation or development; and other or unknown methods. We also identified subcategories of individual research methods (Table 1). If more than one method formed the basis of the publication, the publication was classified as using a mixed method. If the author of the publication did not mention the method in the publication, we assigned one.

DofC 3 was used to classify the content of each publication. In line with Kaldalóns and Macdonald (2005), we used the framework from Holbrook et al. (2000, Table 3.5). We judged it important to modify the framework in order to adjust to recent educational trends and knowledge and the Icelandic school system in general by adding the history category and slightly changing others. Thus, we ended up with ten categories (see first part of Table 2) instead of the nine from Holbrook et al. within our content dimension. The categories are: teaching and learning; physical, mental and social wellbeing; the educational system; curricular subjects; society; administration and the labour market; information and communication technology; methodology; the working environment; and history. If the publication could be placed in more than one category, we selected the predominant category, and thus, in the content analysis, each publication was only placed in one category.

DofC 4 involved identifying the presumed target audience of the publications. Here, we drew on the concept of a helix to determine what groups of audiences or stakeholders could be considered to be the primary target. The quadruple helix model (Etzkowitz \& Leydesdorff 2000; Park 2014) draws attention to the various stakeholders that must be taken into account if research is to be utilised on a large scale in society. The helix invites a focus on the interaction and relationship among practitioners, policy makers, universities, and civil society. In the model, universities play an important role in facilitating change by increasing knowledge through publications and channelling it to the other stakeholders in order to support change.

Here, the model is used to highlight the connections among practitioners in the field (in this case, upper secondary schools), the policy makers (most importantly, the Ministry of Education, Science and Culture), universities, and participants in civil society and how these actors are linked to knowledge production and potential educational change. Therefore, we evaluated the primary target audience under the following four groups: practitioners in the field, essentially those employed in the schools, particularly teachers, councillors, and school leaders; policy makers, primarily within the Ministry of Education, Science and Culture in Iceland; universities, mainly in Iceland; and civil society, such as parents and industry, as important stakeholder groups. These four main groups are shown in the helix model in Table 2. Then, we also identified a secondary audience in relevant publications, acknowledging that the authors sometimes address multiple audiences. The quadruple helix assumes four groups of stakeholders, but no publication could be placed in the category civil society. Thus, there are only three categories in the 
helix part of Table 2. However, it should be noted that almost all the publications are open to the public.

DofC 5 was used to identify the formal structure of each publication and its more exact content than in DofC 3, since in included the aims, purposes, research questions, hypothesis, key words, and the specific content of the publications. This data was analysed and categorised into themes. Two main themes are reported with several subthemes: growth of educational opportunities at the university level and policy making and main trends in education.

\subsection{The value and limitations of the study}

While the study is a continuation of the previous Kaldalóns and Macdonald study from 2005 , focusing on the overall school system, this study focuses solely on upper secondary education. The period of study spans ten years as compared to five years in the earlier study. It is important to draw attention to the diversity of the publications in the study because they touch upon various stakeholders in the field of upper secondary education.

The limitation of the study is mainly related to the availability of the publications. We may also have missed some authors studying or working abroad or within different academic areas. Therefore, if publications were produced by experts working in a university abroad, they may not be included. Furthermore, we were unable to access some publications, mainly within the theses category, as they were either stored abroad, closed to the wider public, or only the abstracts were published. Thus, we did not have the opportunity to evaluate all the categories in detail and instead identified them as missing.

\section{Findings}

In the findings, we begin by providing an overview of the dataset where we discuss the types of publications, data collection methods, most frequent topics of the publications, and the target audience. This is followed by a discussion of the findings from the perspective of the main publication categories. Finally, we discuss two issues that touch upon educational opportunities and the research trends on upper secondary education.

\subsection{The availability of publications targeted at upper secondary education in Iceland}

Over the ten-year period, the frequency of publications related to upper secondary education in Iceland increased from 18 in 2003 to 62 in 2012 (Figure 2). Innovation reports first appeared in 2009 with the establishment of the Innovation Fund (Sprotasjóður n.d.) for educational development work in pre-schools, compulsory schools, and upper secondary schools. Further, Figure 2 shows an increase in the number of theses and external evaluation reports, while the numbers of peer-reviewed publications and nonreviewed scholarly work remained more or less constant over the decade. The number of innovation reports was also constant for the short period they appear in the data. 


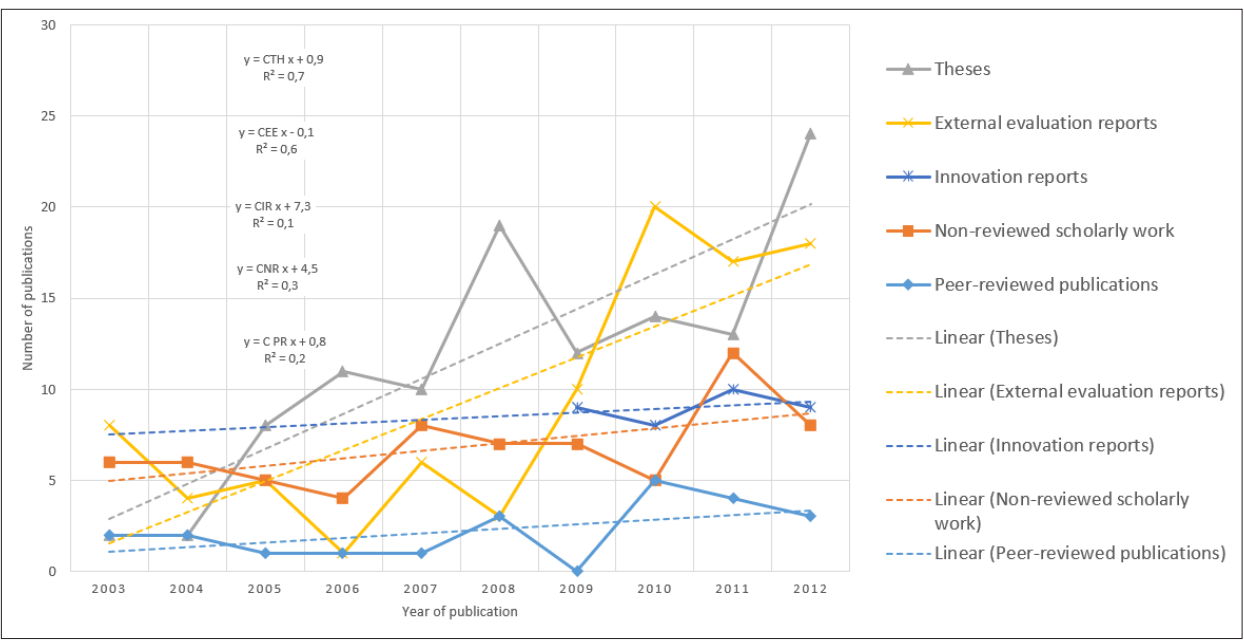

Figure 2. Quantitative development of the publications for the years 2003-2012 Note: Innovation reports begin in 2009.

The method of data collection used in in the publications presented in Table 1 was somewhat diverse. Publications using qualitative research methods were the most common $(33 \%)$ with interviews as the most frequent subcategory. Mixed methods were used in $26 \%$ of the publications. A combination of qualitative and quantitative methods was the most common mixed methodology. These included interviews and surveys. Thus, qualitative methods were used in well above half of the publications studied.

Table 1. Classification of research methods using DofC 2

\begin{tabular}{|c|c|c|c|c|c|c|c|c|c|c|c|c|c|c|c|c|c|c|c|c|c|c|c|c|c|c|c|c|c|}
\hline & & Mix & ed $n$ & net & & & & & & & & & & nly & quar & ntitz & ative & & & Actic & on $r$ & esea & & & 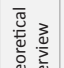 & 젛 & 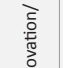 & 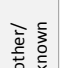 & \\
\hline & 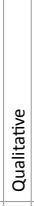 & 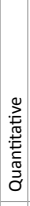 & 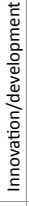 & & N (\%) & 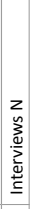 & 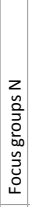 & 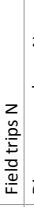 & & & 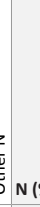 & & 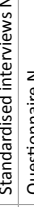 & 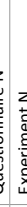 & 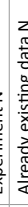 & & $\begin{array}{ll}N(\%) \\
N(2)\end{array}$ & 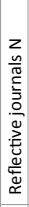 & 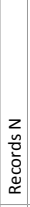 & $\begin{array}{l} \\
z \\
\sum_{0}^{n} \\
\sum_{0}^{0} \\
\underline{\underline{d}} \\
\underline{\underline{d}}\end{array}$ & & & है & $\mathrm{N}$ (\%) & $\mathrm{N}(\%)$ & N (\%) & N (\%) & $N(\%)$ & N (\%) \\
\hline In total & 70 & 72 & 2 & 4 & $\begin{array}{c}72 \\
(26 \%)\end{array}$ & 80 & 15 & 201 & 5 & 7 & $\begin{array}{r}9 \\
133\end{array}$ & & 15 & 36 & 9 & 4 & $\begin{array}{c}66 \\
(23 \%)\end{array}$ & 11 & 3 & 7 & 7 & 5 & 5 & $\begin{array}{r}16 \\
(6 \%)\end{array}$ & $8(3 \%)$ & $6(2 \%)$ & $9(3 \%)$ & $\begin{array}{r}12 \\
(4 \%)\end{array}$ & $\begin{array}{r}291 \\
(100 \%)\end{array}$ \\
\hline $\begin{array}{r}\text { Peer-reviewed } \\
\text { publications }\end{array}$ & 4 & 4 & 0 & 0 & $\begin{array}{c}4 \\
(15 \%)\end{array}$ & 12 & 2 & 3 & 1 & 0 & $\begin{array}{r}1 \\
46\end{array}$ & 6) & \begin{tabular}{l|l}
1 & 5
\end{tabular} & 0 & 0 & 1 & $\begin{array}{c}6 \\
(23 \%)\end{array}$ & 1 & 1 & 0 & 1 & 0 & 1 & $\begin{array}{r}1 \\
(4 \%)\end{array}$ & $\begin{array}{r}3 \\
(12 \%)\end{array}$ & $0(0 \%)$ & $0(0 \%)$ & $0(0 \%)$ & $\begin{array}{r}24 \\
(100 \%)\end{array}$ \\
\hline $\begin{array}{r}\text { Non-reviewed } \\
\text { scholarly work }\end{array}$ & 11 & 11 & 0 & 0 & $\begin{array}{c}11 \\
(11 \%)\end{array}$ & 20 & 1 & 10 & 6 & 5 & $\begin{array}{r}2 \\
129\end{array}$ & & \begin{tabular}{l|l}
0 & 2
\end{tabular} & 3 & 6 & 2 & $\begin{array}{c}30 \\
(31 \%)\end{array}$ & 3 & 0 & 0 & 1 & 1 & 0 & $\begin{array}{r}3 \\
(3 \%)\end{array}$ & $4(4 \%)$ & $5(5 \%)$ & $7(8 \%)$ & $9(9 \%)$ & $\begin{array}{r}97 \\
(100 \%)\end{array}$ \\
\hline Theses & 15 & 17 & 2 & 4 & $\begin{array}{c}17 \\
(15 \%)\end{array}$ & 40 & 8 & 6 & 3 & 2 & $\begin{array}{r}4 \\
138\end{array}$ & 6) & $\begin{array}{lll}0 & 2\end{array}$ & 53 & 2 & 1 & $\begin{array}{c}28 \\
(24 \%)\end{array}$ & 7 & 2 & 7 & 5 & 4 & 3 & $\begin{array}{r}11 \\
(10 \%)\end{array}$ & $1(1 \%)$ & $1(1 \%)$ & $2(2 \%)$ & $\begin{array}{r}11 \\
(10 \%)\end{array}$ & $\begin{array}{r}115 \\
(100 \%)\end{array}$ \\
\hline $\begin{array}{r}\text { External evalua- } \\
\text { tion reports }\end{array}$ & 32 & 32 & 0 & 0 & $\begin{array}{c}32 \\
(78 \%)\end{array}$ & 6 & 3 & 1 & 5 & 0 & (15 & 6) & 0 & 0 & 1 & 0 & $1(2 \%)$ & 0 & 0 & 0 & 0 & 0 & 0 & $0(0 \%)$ & $0(0 \%)$ & $0(0 \%)$ & $0(0 \%)$ & $2(5 \%)$ & $\begin{array}{r}41 \\
(100 \%)\end{array}$ \\
\hline $\begin{array}{r}\text { Innovation } \\
\text { reports }\end{array}$ & 8 & 8 & 0 & 0 & $\begin{array}{c}8 \\
(67 \%)\end{array}$ & 2 & 1 & 0 & 0 & 0 & (17) & 6) & \begin{tabular}{l|l}
0 & 1
\end{tabular} & 0 & 0 & 0 & $1(8 \%)$ & 0 & 0 & 0 & 0 & 0 & 1 & $1(8 \%)$ & $0(0 \%)$ & $0(0 \%)$ & $0(0 \%)$ & $0(0 \%)$ & $\begin{array}{r}12 \\
(100 \%)\end{array}$ \\
\hline
\end{tabular}


The most frequent content focus of the publications, or $23 \%$, was linked to teaching and learning as identified (Table 2). Of the 71 publications in that category, the most frequent topics were student dropout $(\mathrm{N}=20)$ and teaching $(\mathrm{N}=19)$. The second largest topic was the curricular subjects $(19 \%)$, where the three mandatory academic subjects of Icelandic, mathematics and English were the dominant topics of the 58 publications in this category. Other curricular subjects, such as the natural sciences, history, and philosophy, were also present but to a lesser degree. There was a notable gap in the research content when it came to subjects related to vocational studies and the arts.

Table 2. The content (DofC 3 ) and the dimensions of the quadruple helix (DofC 4)

\begin{tabular}{|c|c|c|c|c|c|c|c|c|c|c|c|c|c|c|c|}
\hline & \multicolumn{11}{|c|}{ Content } & \multicolumn{4}{|c|}{ The helix } \\
\hline & 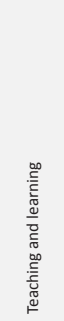 & 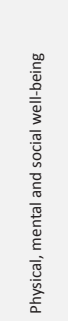 & 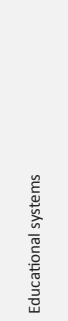 & 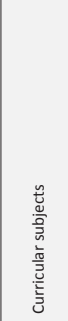 & 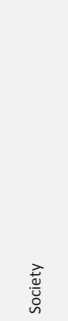 & 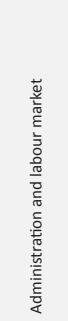 & 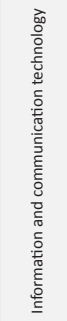 & 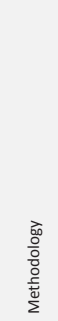 & 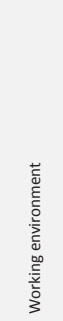 & $\begin{array}{l}\frac{Z}{0} \\
\frac{0}{\underline{\underline{t}}}\end{array}$ & 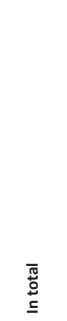 & 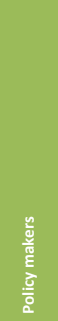 & 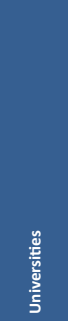 & 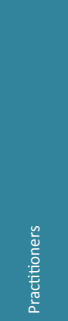 & 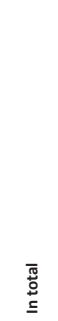 \\
\hline In total & $\begin{array}{c}71 \\
(23 \%)\end{array}$ & $\begin{array}{c}39 \\
(13 \%)\end{array}$ & $\begin{array}{c}30 \\
(10 \%)\end{array}$ & $\begin{array}{c}58 \\
(19 \%)\end{array}$ & $13(4 \%)$ & $16(5 \%)$ & $16(5 \%)$ & $4(1 \%)$ & $\begin{array}{l}57 \\
(18 \%)\end{array}$ & $5(2 \%)$ & $\begin{array}{c}309 \\
(100 \%)\end{array}$ & $\begin{array}{c}134 \\
(42 \%)\end{array}$ & $16(5 \%)$ & $\begin{array}{l}166 \\
(53 \%)\end{array}$ & $\begin{array}{c}316 \\
(100 \%)\end{array}$ \\
\hline $\begin{array}{l}\text { Peer-reviewed } \\
\text { publications }\end{array}$ & $5(19 \%)$ & $4(15 \%)$ & $4(15 \%)$ & $5(19 \%)$ & $1(4 \%)$ & $1(4 \%)$ & $1(4 \%)$ & $1(4 \%)$ & $4(15 \%)$ & $0(0 \%)$ & $\begin{array}{c}26 \\
(100 \%)\end{array}$ & $\begin{array}{c}13 \\
(50 \%)\end{array}$ & $2(8 \%)$ & $\begin{array}{c}11 \\
(42 \%)\end{array}$ & $\begin{array}{c}26 \\
(100 \%)\end{array}$ \\
\hline $\begin{array}{l}\text { Non-reviewed } \\
\text { scholarly work }\end{array}$ & $\begin{array}{l}20 \\
(21 \%)\end{array}$ & $7(7 \%)$ & $\begin{array}{c}12 \\
(12 \%)\end{array}$ & $\begin{array}{c}23 \\
(24 \%)\end{array}$ & $4(4 \%)$ & $8(8 \%)$ & $2(2 \%)$ & $1(1 \%)$ & $\begin{array}{c}16 \\
(16 \%)\end{array}$ & $4(4 \%)$ & $\begin{array}{c}97 \\
(100 \%)\end{array}$ & $\begin{array}{c}46 \\
(47 \%)\end{array}$ & $8(8 \%)$ & $\begin{array}{c}44 \\
(41 \%)\end{array}$ & $\begin{array}{c}98 \\
(100 \%)\end{array}$ \\
\hline Theses & $\begin{array}{c}31 \\
(27 \%)\end{array}$ & $\begin{array}{c}24 \\
(21 \%)\end{array}$ & $4(3 \%)$ & $\begin{array}{c}23 \\
(20 \%)\end{array}$ & $5(4 \%)$ & $7(6 \%)$ & $\begin{array}{c}11 \\
(10 \%)\end{array}$ & $0(0 \%)$ & $9(8 \%)$ & $1(1 \%)$ & $\begin{array}{c}115 \\
(100 \%)\end{array}$ & $\begin{array}{c}34 \\
(29 \%)\end{array}$ & $6(5 \%)$ & $\begin{array}{c}76 \\
(66 \%)\end{array}$ & $\begin{array}{c}116 \\
(100 \%)\end{array}$ \\
\hline $\begin{array}{l}\text { External } \\
\text { evaluation reports }\end{array}$ & $4(10 \%)$ & $1(2 \%)$ & $1(2 \%)$ & $6(15 \%)$ & $1(2 \%)$ & $0(0 \%)$ & $1(2 \%)$ & $0(0 \%)$ & $\begin{array}{l}27 \\
(67 \%)\end{array}$ & $0(0 \%)$ & $\begin{array}{c}41 \\
(100 \%)\end{array}$ & $\begin{array}{c}42 \\
(100 \%)\end{array}$ & $0(0 \%)$ & $0(0 \%)$ & $\begin{array}{c}42 \\
(100 \%)\end{array}$ \\
\hline Innovation reports & $\begin{array}{c}13 \\
(36 \%)\end{array}$ & $3(8 \%)$ & $\begin{array}{c}10 \\
(27 \%)\end{array}$ & $5(14 \%)$ & $2(6 \%)$ & $0(0 \%)$ & $1(3 \%)$ & $2(6 \%)$ & $0(0 \%)$ & $0(0 \%)$ & $\begin{array}{c}36 \\
(100 \%)\end{array}$ & $0(0 \%)$ & $0(0 \%)$ & $\begin{array}{c}36 \\
(100 \%)\end{array}$ & $\begin{array}{c}36 \\
(100 \%)\end{array}$ \\
\hline
\end{tabular}

The primary target audience (53\%), from the viewpoint of the quadruple helix, was practitioners in the field. The second most common target audience (42\%) was policy makers (Table 2). The emphasis on the primary target audience varied between the three main publication categories.

\subsection{The nature of the publications}

The number of peer-reviewed publications targeted at upper secondary education has minor fluctuations (Figure 2). There were two articles published in 2003 and only three in 2012. When analysing the authors' names, 16 university-based researchers published 15 of the 26 peer-reviewed articles during this ten-year period, and nine of these articles were co-authored with graduate students. Qualitative research designs were most common in this category, or $46 \%$, and interviews were the predominant subcategory (Table 1). The frequency of publications focusing on teaching and learning was similar to the 
number of publications on curriculum subjects (Table 2). The primary target audiences were policy makers and practitioners in the field (Table 2).

The number of non-reviewed scholarly works was also fairly constant (Figure 2), starting with six publications in 2003 and rising to eight in 2012. However, we see a greater diversity in methods than in the peer-reviewed publications (Table 1). The content of of non-reviewed scholarly works was similar to that the peer-reviewed publications, while the writing was more targeted towards policy makers (Table 2).

The numbers of master's and doctoral theses looking at upper secondary education increased from two in 2003 to 24 in 2012, and the correlation between the number of publications and time was significant (Figure 2). Qualitative methods (38\%) were most common and interviews were the most frequent subcategory. Quantitative methods $(24 \%)$ in the form of questionnaires come after qualitative methods and then studies which used a combination of interviews and questionnaires (Table 1). Teaching and learning and physical, mental and social wellbeing were the most frequent topics within the categories of theses, and the primary target audience was practitioners in the field (Table 2).

The number of external evaluation reports increased from eight in 2003 to eighteen in 2012, and as with the theses category, the correlation is significant (Figure 2). These reports seem to have been written by university-based researchers, private agents, stakeholders, and practitioners in field. The focus of the external evaluation reports was mainly on efficiency, structures, human resources, and the school policy documents, and there was very little focus on what takes place in the classrooms. When there was such a focus, it was on teaching and learning. The most frequent methods in use in evaluation reports were a combination (78\%) of interviews, questionnaires, and accessible data that are part of everyday school practices (Table 1). The working environment (67\%) was the most common content of the reports (Table 2). The classification of the target audience of the external evaluation reports was not simple, since the dual purpose of external evaluation is to monitor upper secondary school practices in a transparent and publicly open manner and to encourage school improvement. But, when looking at the content of the reports, there was a greater focus on monitoring the schools than improving educational practices from a pedagogical standpoint. We therefore identified policy makers as the target audience for the reports (Table 2).

The Innovation Fund (Sprotasjóður n.d.) supports projects annually with approximately 45 million ISK (around 280 thousand Euros as of May 2012), roughly equivalent to the combined salary of six to seven upper secondary school teachers at the time. The acceptance ratio of the applications for all the three school levels varied from $24-37 \%$ (Table 3), and upper secondary education received, on average, one third of the total funds each school year. The focus of the Innovation Fund varies each year (Table 3). For most of the years studied, the focus was influenced by the national curriculum guide that was being designed after legislative changes in 2008 and enacted in 2011 (Ministry of Education, Science and Culture 2012). Since 2008, 67\% of upper secondary schools have received grants. A single upper secondary school received $16 \%$ of the total funding 
over these four years. Three schools received $40 \%$ of the funding, and three schools had four grants. Upper secondary schools and universities carried out two funded cooperative activities during the four-year funding period.

Table 3. The Innovation Fund focus and application acceptance rate

\begin{tabular}{l|l|c}
\hline Year & Focus & Acceptance rate \\
\hline $\mathbf{2 0 0 9 - 2 0 1 0}$ & $\begin{array}{l}\text { Flexibility and diversity in learning and teaching methods. } \\
\text { Literacy and literacy education in the broad sense of the term. }\end{array}$ & $\mathbf{3 1 \%}$ \\
\hline $\mathbf{2 0 1 0 - 2 0 1 1}$ & $\begin{array}{l}\text { Schools' connections with the local community with a focus on } \\
\text { sustainability. } \\
\text { Student transitions between school levels: Learning and teaching. } \\
\text { Well-being in schools. }\end{array}$ & $\mathbf{3 7 \%}$ \\
\hline $\mathbf{2 0 1 2 - 2 0 1 3}$ & $\begin{array}{l}\text { Ethics and critical thinking. } \\
\text { Creative learning: Innovation in the learning environment. }\end{array}$ & $\mathbf{2 6 \%}$ \\
\hline
\end{tabular}

The most common evaluation approach in the innovation reports was based on the professional judgement of the report authors, most often the coordinator of the project. Only 13 (23\%) of the innovation reports had an explicit link to different kinds of data collection methods to evaluate the outcomes of the innovation project. Mixed methods were the most frequent category, mainly a combination of interviews and questionnaires (Table 1), and the most common content was teaching and learning (Table 2).

\subsection{Educational opportunities, policy making, and main trends in upper second- ary education research}

Two issues in the data deserve special attention. These are new educational opportunities at the university level (Table 4), and policy making and main trends in research on upper secondary education.

Table 4. The number of theses by university

\begin{tabular}{|c|c|c|c|c|c|c|c|c|c|c|c|}
\hline Year & 2003 & 2004 & 2005 & 2006 & 2007 & 2008 & 2009 & 2010 & 2011 & 2012 & In total \\
\hline $\begin{array}{l}\text { Iceland University } \\
\text { of Education }\end{array}$ & 1 & 1 & 1 & 1 & 1 & & & & & & $5(4 \%)$ \\
\hline $\begin{array}{l}\text { University of } \\
\text { Akureyri }\end{array}$ & & & & & & 2 & & 1 & 2 & 3 & $8(7 \%)$ \\
\hline $\begin{array}{l}\text { University of } \\
\text { Iceland }\end{array}$ & 1 & 1 & 7 & 10 & 7 & 14 & 12 & 12 & 10 & 20 & $94(82 \%)$ \\
\hline $\begin{array}{l}\text { Reykjavík Uni- } \\
\text { versity }\end{array}$ & & & & & 2 & 3 & & & 1 & & $6(5 \%)$ \\
\hline Other & & & & & & & & 1 & & & $1(1 \%)$ \\
\hline
\end{tabular}


The growth of educational opportunities at the university level is linked to the development and diversity of publications targeted at upper secondary education in Iceland. In the mid-1990s, the Iceland University of Education (Kennaraháskóli Íslands) began to offer master's programmes that focused on educational management and inclusive special education (Hálfdanarson, Matthíasdóttir, \& Guðmundsson 2011). In the first part of the research period (2003-2007), five master's theses were written in Iceland University of Education. Two focused on the use of information and communication technology (ICT), two on disability studies, and one on the natural sciences.

In 1993-1994, the University of Iceland (Háskóli Íslands) began to offer master's programmes in Education Studies within the Faculty of Social Science. From 1998 and onwards, the Faculty of Social Science began to offer a wider range of specialist areas (Aðalbjarnardóttir 2015). As the data indicate, the University of Iceland has produced most of the theses throughout the research period (Table 4). Pedagogy and curricular subjects have been recurring research themes, mostly the academic subjects, but also curriculum critique, ICT, and disability studies, reflecting some of the subject areas in the university. Moreover, studies on the topic of student dropout were urgent and increased rapidly as it became a significant research topic.

Early in the 21st century, the University of Akureyri (Háskólinn á Akureyri) also started to focus on degrees in education and producing master's students (Hálfdanarson et al. 2011). During the second part of the research period, eight master's theses discussing diverse aspects of upper secondary education were written at the University of Akureyri (Table 4). The theses' foci are diverse: one each on school development, ICT, and motivation; two on students who have not met the entrance requirements for other programmes in upper secondary education; and one each on life skills, history, and mathematics.

In the first decade of the 20th century, graduate programme options began to diversify within the University of Iceland (Hálfdanarson et al. 2011). In 2005, the faculty of Education and Public Health was established within Reykjavík University (Háskólinn i Reykjavik) (Reykjavík University 2007). Therefore, from 2005 onwards, we see an increased number of theses as well as greater diversity of master's programmes enriching the scope of educational research in Iceland. Examples include master's programmes in public administration (MPA) and public health (MPH). These new learning opportunities increased the number of theses focusing on students' and teachers' wellbeing, on public administration, and on multicultural education. In 2008, a few study programmes within the University of Iceland and Iceland University of Education merged to become School of Education (Menntavísindasvið) (Aðalbjarnardóttir 2015).

In the 1997-1998 academic year, the University of Iceland began offering doctoral programmes in the field of education and the Iceland University of Education was given permission by the Ministry of Education in late 2001 to do the same. In the beginning, none of the doctoral candidates focused on upper secondary education (Aðalbjarnardóttir 2015). Iceland University of Education graduated its first $\mathrm{PhD}$ candidates in the spring of 2008, just before the merger of the two universities. As the time passed, an increasing number of $\mathrm{PhD}$ candidates focused on upper secondary education. 
In 2008, comprehensive legislation on education, including the Upper Secondary Education Act (No. 92/2008), was passed, and the financial crisis hit. A number of projects considered the consequences of the act and the financial crisis. Some authors who are members of certain subject areas or academic programmes were concerned about their subjects and a possible reduction of the study paths leading to academic programmes. They, therefore, carried out research on job security and the importance of the subject they taught. One of the 2008 legislative changes was the new Act on the Education and Recruitment of Teachers and Administrators of Preschools, Compulsory Schools and Upper Secondary Schools No. 87/2008. The act stated that, after 2011, most academic teachers would be required to obtain a master's degree in order to have a license to teach. This is most likely the chief explanation of the growth in number of master's theses in 2011 (Figure 2).

After the Ministry of Education, Science and Culture (2012) published the National Curriculum Guide in 2011 with its emphasis on decentralisation, the debate discussed above waned, and the research focus moved on to new opportunities in place of social tensions and the economic crisis. The six fundamental pillars of literacy, democracy and human rights, creativity, health and wellbeing, equality, and sustainability were introduced and impacted the focus of the research, along with an increased emphasis on assessment, teaching, and the management of educational change.

\section{Discussion}

The availability and nature of evidence-based publications targeted at upper secondary education in Iceland have been the objects of discussion. As traced in the introduction and Section 1.1, university-based researchers have complained about the lack of research publications looking at upper secondary education (Guðmundsson 2009; Jóhannesson 2007; Jóhannsdóttir \& Jónasson 2014; Thorarensen, Vilmundarson, \& Hilmarsson 2008). Still, more publications than expected fulfilled our research criteria. The study shows that there is considerable material focused on upper secondary education in Iceland. Much of it addresses specific issues within the educational arena (universitybased publications), is directly targeted at individual schools (external evaluation reports), or is specific to particular projects (the innovation reports). The characteristics of the publications varied greatly along all the dimensions of analysis.

\subsection{The nature of the publications}

We asked in the beginning, what characterised evidence-based publications focusing on upper secondary education in Iceland? More publications and an increased diversity of content emerged during the research period. Moreover, the growth of educational opportunities in universities along with policy making and trends in education positively impacted the scope of evidence-based publications. Nevertheless, there are limitations and gaps regarding both the content and the data collection methods.

The core subjects of Icelandic, English, and mathematics and other academic subjects dominated the choice of research topics at the expense of other fields, such as 
vocational subjects, possibly due to different educational demands among groups of teachers or because of different statuses and gaps between vocational and academic subjects (Eiríksdóttir, Ragnarsdóttir, \& Jónasson 2018). Since only academic teachers are expected to hold a master's degree, this may impact the number of publications in other subjects as well.

Similar patterns of methods were used in all three categories of university-based publications (peer-reviewed, non-reviewed scholarly work, and theses), something that Sleeter (2014) also noted when examining several peer-reviewed articles on education. Interviews and questionnaires were widely used at some cost to the use of the full spectrum of data-collection methods as well as other kinds of mixed methods. Similarly, Guðjónsdóttir (2011) examined articles, books, and theses in Iceland based on action research. She noted that the authors relied mainly on reflective journal writing and interviews instead of using a wider scope of methods. This is in line with our assessment of action research, and the other categories of methods in general. The full range of possibilities in methods was not used, which may lead to problems when informing policy, while policy makers tend to idolise quantitative methods (Hemsley-Brown \& Sharp 2003; Nelson et al. 2009).

There is another potential limitation in terms of how controlling the Ministry of Education, Science and Culture (2010) is in its instructions to evaluators when writing external evaluation reports. The focus is mainly on efficiency, structures, human resources, and school policy documents and very little on what happens in the classroom. Therefore, the ministry's demands may block other important aspects of schooling, especially teaching and learning. Furthermore, the external evaluation reports do not link to previous knowledge and theories in education. The potential of the external exercises may, therefore, be lost. Ragnarsdóttir (2018) claims, however, that school leaders in upper secondary education tend to rely more on external evaluation reports than university-based publications. Reports have value for the everyday work of leading their schools.

The Innovation Fund (Sprotasjódur) was established in 2009, but the demand for grants continues to exceed the funds. Of further concern is that the centralised function of the Innovation Fund conflicts with the decentralised ideology in legislations on schools (Upper Secondary School Act No. 92/2008). The fund determines the focus for each funding period while the legislations give schools more freedom to possibly focus on something different than the fund. Yet, the fund aims to opportunities for other topics out of the agenda. The funding committee rarely accepted applications outside the agenda. This emphasis could possibly lead to restricted creativity in the schools.

\subsection{The producers and users of the publications and their interconnectedness}

The growth in evidence-based publications reflects new educational opportunities at the graduate level. Simultaneously, more diverse topics and types of research have been published. Ragnarsdóttir (2018) argues that the additional formal education of upper secondary school teachers and school leaders has become valuable for the development of upper secondary schools. Those who add to their university studies disseminate new ideas when 
they return to the workplace and focus on making change in their own schools.

Most of the publications mapped in this study were targeted at more than one type of audience, similar to what is seen internationally (Hammersley 2002; Mortimore 2000; Yates 2004). The innovation reports were primarily targeted at school practices, while one of the main aims of the external evaluation reports was to monitor the performance of schools (Ministry of Education, Science and Culture 2010), aiming at policy makers and leaders in the assessed school. In this context, it should be noted that an important reason for placing the external evaluation reports on the internet is to make them available to a wider audience, such as, students and their parents.

The study suggests that the primary audience for the university-based publications in Iceland, particularly the master's theses, may be the practitioners in the field, which is at odds with what Sleeter (2014) and Levin (2004) argue when they say that only a few articles are written directly for practitioners and policy makers. The findings indicate that the majority of university-based publications were theses written by practitioners adding to their formal education. These theses are inspired by the individual author's ideas, personal experience, or interest. Relatively few authors take their theses onto peerreviewed journals or other forms of publications, which would increase the visibility of the research and perhaps enhance their general use.

Ragnarsdóttir (2018) argues that school leaders in upper secondary education in Iceland neglect the university-based publications and the work of researchers when leading educational change in their schools. Nonetheless, the evaluation reports targeted directly at their schools seem to have an impact. In general, the school leaders tended to value the outcome of external evaluation reports more than university-based publications.

The evidence-based publications did not provide a strong link to the main stakeholders, for which there could be several reasons. Carrying out research is expected of university-based researchers as a part of their duties. They tend to develop their own ideas, often isolated from educational practitioners (Hemsley-Brown \& Sharp 2003; Morrison 2007; Nelson et al. 2009) and policy makers (Sleeter 2014).

The external evaluation reports aimed, however, at monitoring the schools, and, in principle, they should as they are meant to facilitate change. The school under evaluation must provide an action plan as a supplement to the report in which the school addresses the steps intended to implement change. The primary target audience for external evaluation reports is policy makers to fulfil the monitoring requirement and, secondarily, practitioners as they are expected to enact the recommended the changes in their schools (Ministry of Education, Science and Culture 2010; Upper Secondary Education Act No. 92/2008). The external evaluation reports relied largely on mixed methods and tend to be wider in scope than the university-based publications. In general, external evaluation reports do not rely on the suggestions and outcomes made by university-based publications. Therefore, there was a notable gap between universitybased research and external evaluation reports.

Based on our data, the link between university-based publications and innovation reports was also weak. Only a few of the funded projects were based on existing research 


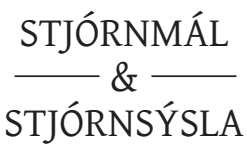

knowledge, and just a quarter of the innovation reports included data collection when assessing outcomes. Kaldalóns and Macdonald (2005) suggest that ideas for innovation have their source in universities. This study is at odds with their argument, as only two out of the 31 funded innovation activities were carried out in cooperation between practitioners in upper secondary schools and the universities.

Interaction with and inclusion of civil society was not found to be a part of the existing assessed structures. Furthermore, the university-based research, external evaluation reports gathered by policy makers, and the Innovation Fund exist and function in isolation from each other. This underscores the idea that effective development would benefit from an explicit and engineered constructive interaction of the stakeholders present in the helix model (Etzkowitz \& Leydesdorff 2000; Park 2014). Hence, we argue that a link is needed to build connections among university-based publications, external evaluation reports, and innovation reports in order to better connect existing information and facilitate change. In building such a link, we may be able to reduce the hierarchy of different kinds of evidence (Nutley et al. 2013). Understanding and valuing different kinds of evidence need attention, as does gaining a balance between evidence origins and general use. Through this, the value of diverse types of publications would be increased. The helix dimensions could integrate ideas of university-based work, external evaluation, and innovation with a more comprehensive picture of educational practices and general ideas of what works and how it works.

Facilitating communication between the different stakeholders of the quadruple helix would provide opportunities to encourage the professionals involved to make changes in their own practices, including training and support in the use of different kinds of evidence. Existing knowledge of the potential effectiveness of the various types of university work, both in individual endeavours as well as in team efforts, to develop a whole school approach towards educational change would be useful (Fullan 2007; Hargreaves \& Fullan 2012). The increased interactive connections among the dimensions of the quadruple helix (Etzkowitz \& Leydesdorff 2000; Park 2014) could include visits, support teams, adaptive procedures, and continuous professional development. It could also involve increased time dedicated to research, such as sabbaticals, joint authorship between supervisor and student, and cooperation between stakeholders and schools as an important aspect of everyday practice.

\section{Final words}

The increase in the number of evidence-based publications focusing on upper secondary education surprised the researchers. Most of the publications in the three main categories have latent value for schools and learning. Means should be found to release some of that latent energy to serve school development more directly. The methods tended to be homogeneous, with clear emphasis on interviews and action research in the form of reflective journaling. However, policy makers tend to value quantitative methods more. Therefore, we call for discussion on how such varied materials might, in principle and in practice, become useful for school development and university research- 
ers. The quadruple helix is a candidate for such a structure. In a white paper (Hvitbók um umbatur i menntun) from the Ministry of Education, Science and Culture (2014), there is a call for university-based research that could inform development and encourage increased use of different types of evidence to influence educational discourse in Iceland. A similar and very direct call came from an educational leader at OECD, van Damme (2019), when he called for a closer link between educational research and development.

Considerable amount of publications has been produced to meet university expectation. Nearly half of the doctoral candidates have defended their theses after the study period ended (see for example, Blöndal 2014; Ragnarsdóttir 2018), and others who focus on upper secondary education have initiated their studies (Gestsdóttir, van Drie, \& van Boxtel 2019; Jónsson, Smith, \& Geirsdóttir 2018). The team behind the research project on Upper Secondary School Practices published a thematic issue of Netla in 2018. It contained 11 peer-reviewed articles and two non-reviewed ones (Óskarsdóttir 2018). Some of the team members have also published articles with colleagues from the NordForsk-funded research network Justice through Education in the Nordic Countries (Bjarnadóttir, Öhrn, \& Johansson 2019; Nylund, Rosvall, Eiríksdóttir, Holm, Isopahkala-Bouret, Niemi, \& Ragnarsdóttir 2018). The research project Upper Secondary School Practises was part of that network. As has been portrayed, research and other evidence are growing; the gaps are being filled, and new topics continue enter the scope of educational research in Iceland.

\section{Notes}

1 This research is based on a documentary review funded by Anniversary Fund (Aldarafmalissjótur) of the University of Iceland. We thank Allyson Macdonald her cooperation in the Anniversary Fund project.

2 The School of Education at the University of Iceland provided a list of $25 \mathrm{PhD}$ students who, at the end of 2012, were studying towards their degree.

\section{References}

Aðalbjarnardóttir, S. (2015). "Uppeldis- og menntunarfræði 40 ára háskólagrein á Íslandi: Framhaldsnám við Félagsvísindadeild Háskóla Íslands" [Education studies has been a university subject over 40 years in Iceland: Graduate programme within School of Social Sciences in University of Iceland], Uppeldi og menntun [Icelandic Journal of Education] 24(2), 135-146. Retrieved from https:// timarit.is/page/6370742\#page/n133/mode/2up

Act on the education and recruitment of teachers and administrators of preschools, compulsory schools and upper secondary schools No. 87/2008.

Bjarnadóttir, V.S., Öhrn, E., and Johansson, M. (2019). "Pedagogic practices in a deregulated upper secondary school: Students' attempts to influence their teaching", European Educational Research Journal 18(6), 724-742. doi:https://doi.org/10.1177/1474904119872654

Blöndal, K.S. (2014). Student Disengagement and School Dropout: Parenting Practices as Context (PhD). University of Iceland, Reykjavík.

Bornmann, L., and Mutz, R. (2014). "Growth rates of modern science: A bibliometric analysis based on the number of publications and cited references", Journal of the Association for Information Science \& Technology 66(11), 2215-2222. doi:https://doi.org/10.1002/asi.23329

Cooper, A., Levin, B., and Campbell, C. (2009). "The growing (but still limited) importance of evi- 
Guðrún Ragnarsdóttir

Ingólfur Ásgeir Jóhannesson

Jón Torfi Jónasson

Brynja E. Halldórsdóttir
STJÓRNMÁL

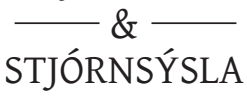

dence in education policy and practice", Journal of Educational Change 10(2), 159-171. doi:https:// doi.org/10.1007/s10833-009-9107-0.

Eiríksdóttir, E. Ragnarsdóttir, G., and Jónasson, J.T. (2018). "Pversagnir og kerfisvillur? Kortlagning á ólíkri stöđu bóknáms- og starfsnámsbrauta á framhaldsskólastigi” [On Parity of Esteem between Vocational and General Academic Programs in Upper Secondary Education in Iceland], Netla - Veftimarit um uppeldi og menntun: Sérrit 2018 - Frambaldsskólinn í brennidepli [Netla - Online Journal on Pedagogy and Education]. Retrieved from http://netla.hi.is/serrit/2018/framhaldskolinn_brennidepli/07.pdf

Etzkowitz, H., and Leydesdorff, L. (2000). "The dynamics of innovation: From national systems and "Mode 2" to a Triple Helix of university-industry-government relations", Research Policy 29(2), 109_ 123.

Evans, L. (2008). Is educational research(ing) a profession? Examining issues of professional status and developmentalism. Paper presented at the Society for Research into Higher Education, Adelphi Hotel, Liverpool.

Fullan, M. (2007). The new meaning of educational change ( $4^{\text {th }}$ ed.). New York: Routledge: Teachers College Press.

Gestsdóttir, S.M., van Drie, J., and van Boxtel, C. (2019). "Teaching historical thinking and reasoning in upper secondary schools in Iceland: results of an observation study", Nordidactica - Journal of Humanities and Social Science Education 2, 1-24.

Guðjónsdóttir, H. (2011). "Rýnt í vinnubrögð starfendarannsókna: Ólíkar leiðir við gagnaöflun” [Action research: Different ways for data collection], Rádstefnurit Netlu-Menntakvika 2011, 1-15. Retrieved from http://netla.hi.is/menntakvika2011/010.pdf

Guðmundsson, G. (2009). “Að fara vanbúinn í langferð. Ný framhaldsskólalög” [Embarking on a long voyage without proper preparation. New law for upper secondary education], Icelandic Journal of Education 18(1), 111-114.

Hammersley, M. (2002). Educational research, policymaking and practice. London: Paul Chapman.

Hammersley, M. (2005). "Is the evidence-based practice movement doing more good than harm? Reflections on Iain Chalmers' case for research-based policy making and practice", Evidence \& Policy: A Journal of Research, Debate and Practice 1(1), 85-100. doi:https://doi.org/10.1186/1479-5876-9-3

Hargreaves, A., and Fullan, M. (2012). Professional capital: Transforming teaching in every school. London: Routledge.

Hálfdanarson, G., Matthíasdóttir, S., Guðmundsson, M., and Karlsson, G. (ed.) (2011). Aldarsaga Háskóla Íslands, 1911-2011 [University of Iceland: History of 100 years, 1911-2011]. Reykjavík: Háskólaútgáfan.

Hemsley-Brown, J., and Sharp, C. (2003). "The use of research to improve professional practice: A systematic review of the literature", Oxford Review of Education 29(4), 449-471. doi:https://doi. org $/ 10.1080 / 0305498032000153025$

Holbrook, A., Ainley, J. Bourke, S., Owen, J., McKenzie, P., Mission, S., and Johnson, T. (2000). "Mapping educational research and its impact on Australian schools", in Higher Education Division Research Evaluation Programme Commonwealth of Australia (ed.), The Impact of Educational research (pp. 15-278). Canberra: Research Evaluation Programme, Higher Education Division, Department of Education, Training and Youth Affairs.

Jóhannesson, I.Á. (2007, 7 June). Menntastefna - menntapólitík - menntastefnufrađi [Education policy, education politics, education politics as a field of study]. Paper presented at the Annual Meeting of the Association of Icelandic Upper Secondary Schools, Húsavík. Retrieved from http://www.ismennt. is/not/ingo/menntastefna.htm

Jóhannsdóttir, G., and Jónasson, J.T. (2014). "External and internal influences on the development of Icelandic higher education", Nordic Studies in Education 34(3), 153-171.

Jónsson, Í.R., Smith, K., and Geirsdóttir, G. (2018). "Shared language of feedback and assessment. Perception of teachers and students in three Icelandic secondary schools", Studies in Educational Evaluation 56, 52-58. doi:https://doi.org/10.1016/j.stueduc.2017.11.003 


\section{STJÓRNSÝSLA}

Kaldalóns, I., and Macdonald, A. (2005). An evaluation of educational research and development in Iceland. Summary. Reykjavík: Icelandic Centre for Research and Ministry of Education, Science, and Culture.

Larsen, P.O., and von Ins, M. (2010). "The rate of growth in scientific publication and the decline in coverage provided by Science Citation Index", Scientometrics 84(3), 575-603. doi:https://doi. org/10.1007/s11192-010-0202-z

Levin, B. (2004). "Making research matter more", Education Policy Analysis Archives 12(56), 1-20.

Lingard, B., and Gale, T. (2010). "Presidential address as pedagogy. Representing and constituting the field of educational research", in T. Gale and B. Lingard (eds.), Educational Research by Association. AARE Presidential Addresses and the Field of Educational Research ( $7^{\text {th }}$ ed.) (pp. 3-22). Rotterdam: Sense.

McMillan, J.H. (2012). Educational research: Fundamentals for the consumer ( $6^{\text {th }}$ ed.). Boston: Pearson.

Ministry of Education, Science, and Culture (2010). Mat á skólastarfi: Áatlun um ytra mat í frambaldsskólum, grunnskólum og leikskólum 2010-2012 [Evaluation in schools: Plan on external evaluation in upper secondary schools, compulsory schools and pre-schools 2010-2012]. Reykjavík: Author.

Ministry of Education, Science, and Culture. (2012). The Icelandic National Curriculum Guide for Upper Secondary Schools. General section. Reykjavík: Author.

Ministry of Education, Science, and Culture (2014). Hvitbók um umbatur í menntun [White paper about educational reform]. Reykjavík: Author.

Morrison, M. (2007). What do we mean by educational research? ( $2^{\text {nd }}$ ed.). London: Sage.

Mortimore, P. (2000). "Does educational research matter?”, British Educational Research Journal 26(1), 5-24. Retrieved from https://search.proquest.com/docview/204848445?accountid=135943

Nelson, S.R., Leffler, J.C., and Hansen, B.A. (2009). Toward a research agenda for understanding and improving the use of research evidence. Portland, OR: Northwest Regional Educational Laboratory.

Nutley, S., Powell, A., and Davies, H. (2013). What counts as good evidence? Provocation paper for the alliance for useful evidence. London: Alliance for Useful Evidence.

Nylund, M., Rosvall, P.-Å., Eiríksdóttir, E., Holm, A.-S., Isopahkala-Bouret, U., Niemi, A.-M., and Ragnarsdóttir. G. (2018). "The academic-vocational divide in three Nordic countries: Implications for socialclass and gender”, Education Inquiry 9(1), 97-121. doi:10.1080/20004508.2018.1424490

Óskarsdóttir, G.G. (2018). "Starfshættir í framhaldsskólum: Aðdragandi og framkvæmd rannsóknar 2012-2018” [Upper Secondary School Practices in Iceland: Research project 2012-2018: Method], Netla - Veftimarit um uppeldi og menntun: Sérrit 2018 - Frambaldsskólinn i brennidepli [Netla - Online Journal on Pedagogy and Education]. Retrieved from http://netla.hi.is/serrit/2018/framhaldskolinn_brennidepli/01.pdf.

Park, H.W. (2014). "Transition from the Triple Helix to N-Tuple Helices? An interview with Elias G. Carayannis and David F. J. Campbell", Scientometrics 99(1), 203-207. doi:https://doi.org/10.1007/ s11192-013-1124-3

Puddy, R.W., and Wilkins, N. (2011). Understanding Evidence Part 1: Best available research evidence. A guide to the continuum of evidence of effectiveness. Atlanta: Centers for Disease Control and Prevention.

Ragnarsdóttir, G. (2018). School Leaders' Perceptions of Contemporary Change at the Upper Secondary School Level in Iceland. Interaction of actors and social structures facilitating or constraining change (PhD). University of Iceland, Reykjavík.

Reykjavík University (2007). Háskólinn i Reykjavík. Ársskýrsla 2007 [Reykjavík University. Annual report 2007]. Reykjavík University. Retrieved from https://www.ru.is/media/baeklingar/Haskolinn-i-Reykjavik-Arsskyrsla_2007.pdf

Sleeter, C. (2014). "Toward teacher education research that informs policy", Educational Researcher 43(3), 146-153. https://doi.org/10.3102/0013189X14528752

Sprotasjóður (n.d.). Sprotasjódur: Leikskólar-grunnskólar - frambaldsskólar [Innovation fund: Kindergarten - compulsory schools - upper secondary schools]. Retrieved from http://www.sprotasjodur.is/3. Evidence-based publications on upper secondary education in Iceland.rtf

Upper Secondary Education Act nr. 92/2008. 


\section{Brynja E. Halldórsdóttir}

\section{STJÓRNSÝSLA}

Thorarensen, J.G., Vilmundarson, L.I., and Hilmarsson, H. (2008). Skil á milli skólastiga, skýrsla unnin fyrir Menntaskólann vid Sund veturinn 2007-2008 [The connection between schools levels, a report for Menntaskólinn við Sund veturinn 2007-2008]. Reykjavík: Sund Upper Secondary School.

van Damme, D. (2019, September). The science of learning. Can it make learning more resilient against the risks of modern education?. Keynote, September 5th, at ECER 2019 (EERA), Hamburg. Retrieved from https://eera-ecer.de/ecer-2019-hamburg/programme/keynote-speakers/dirk-van-damme/

van den Akker, J., Gravemeijer, K., McKenney, S., and Nieveen, N. (2006). Educational design research. London: Routledge.

Yates, L. (2004). What does good education research look like? Situating a field and its practices. Berkshire: Open University Press. 
